\title{
Performance of LLBC-based rotor blade for low speed wind turbine
}

\author{
A. Setiawan*, M. M. Al Gifari, and I. Hamidah \\ Universitas Pendidikan Indonesia, Department of Mechanical Engineering Education, Faculty of Technology and Vocational Education, \\ Bandung, Indonesia
}

\begin{abstract}
The development of wind turbine attracts more attention as a renewable energy that supports green technology. Layer Laminated Bamboo Composite (LLBC) is a bio-composite with bamboo base material which is abundant material and has a relatively lower price. Therefore, LLBC is a prospective material for rotor blades of low speed wind turbine. This study investigates the performance of the LLBCbased rotor blades that have been successfully made previously. This research uses experimental method. Performance of the LLBC-based rotor blades is tested by wind tunnel experiment and then compared with the fiber-based rotor blade available in market. The results showed that the LLBC-based rotor blades require wind speed of $4.6 \mathrm{~m} / \mathrm{s}$ to start rotation, while for the fiber-based rotor blades requires wind speed of $4.7 \mathrm{~m} / \mathrm{s}$. Electrical power generated by the LLBC-blade is still lower than generated by standard blade (fiberglass). At wind speed of $8 \mathrm{~m} / \mathrm{s}$, a vibration occurs that reduce performance of the blades. We conclude that LLBC is a potential material for rotor blades of low-speed wind turbine.
\end{abstract}

\section{Introduction}

Electrification ratio in Indonesia in 2015 was $84.4 \%$ which means that there are 12.000 villages or 36 million Indonesian who do not have access to electricity [1]. Indonesia Ministry of Energy and Mineral Resources targeted 90\% electrification ratio in Indonesia in 2020 with rural areas as the main focus. The government also issued a policy that the energy used should come from the area. Presidential Regulation No. 50/2006 explains that the government targets energy sources by 2025 to come from renewable resources and one of them comes from wind turbines.

Wind energy is a source of energy that consider for some reasons. First, wind energy is available anywhere. Greater solar heating of the earth's surface near the equator than near the northern or southern poles cause planetary wind [2]. The potential of wind energy in Indonesia is $9.8 \mathrm{GW}$, but is realized 1.6 MW. That means only $0.02 \%$ that was already used in Indonesia. Wind speed in Indonesia is categorized to low speed by IEC (International Electrotechnical Commissions). Wind speed in Indonesia ranges from $3 \mathrm{~m} / \mathrm{s}$ to $8 \mathrm{~m} / \mathrm{s}$. Therefore, low speed wind turbine is appropriate to be developed in Indonesia [3].

Materials commonly used to make low-speed wind turbines are Glass Fiber Reinforced Polymer (GFRP) and Carbon Fiber Reinforced Polymer. Both materials have a high strength to weight ratio, but expensive and environmentally unfriendly [4]. Bamboo can be an alternative material to make wind turbine blades. Bamboo is a natural composite that is abundant in
Indonesia. Bamboo combined with polymer will produce strength up to $82 \mathrm{GPa}$. Combination of Bamboo and polymer will produce a material with high strength and weight ratio. One technique for combining bamboo and polymer is LLBC (Laminated Layer Bamboo Composite).

LLBC is created by arranging bamboo just like making a wafer. Bamboo is assumed as wafer and polymer as cream. This arrangement produces high tensile strength. In the previous research, Gombong bamboo was combined with three types of polymer: epoxy resin, AW106 and AV138. The result obtained polymers that produce the best tensile strength was combination of gombong bamboo and AW106. The maximum and average tensile strength of LLBC of gombong bamboo and AW106 were $349 \mathrm{MPa}$ and $284.41 \mathrm{MPa}$, respectively [5]. This LLBC combination is then used as the base material for making low speed wind turbine blade.

\section{Experiment}

In this research, performance of LLBC blade is compared to standard blade in a wind tunnel. As reference for standard wind turbine, we used a horizontal axis wind turbine with a diameter 1.2 meter, power 200 watt, using three blades, initial velocity for rotating at $2.5 \mathrm{~m} / \mathrm{s}$ and nylon-based blades (Figure 1(a)). For comparison, the standard blades wind turbines are then replaced by the blades made using the LLBC technique (Figure 1(b)). LLBC Blades are handmade. The process of making LLBC blade begins with measurement of

\footnotetext{
* Corresponding author: agus_setiawan@upi.edu
} 
standard geometry and blade parameters, then selection of bamboo in accordance with the standard blade size.

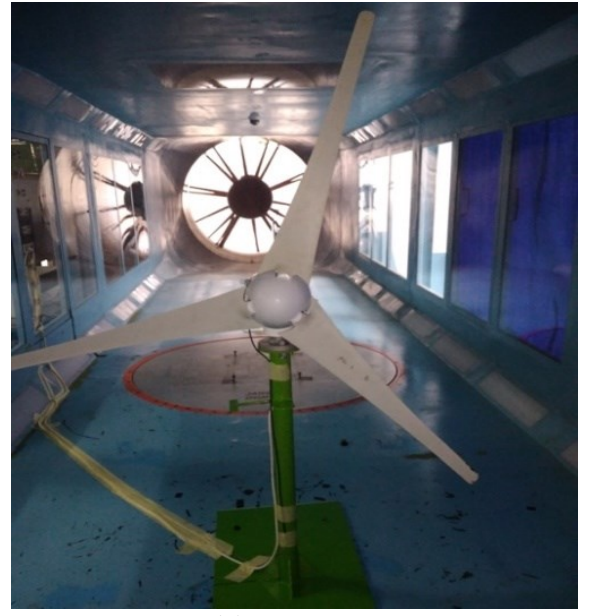

(a)

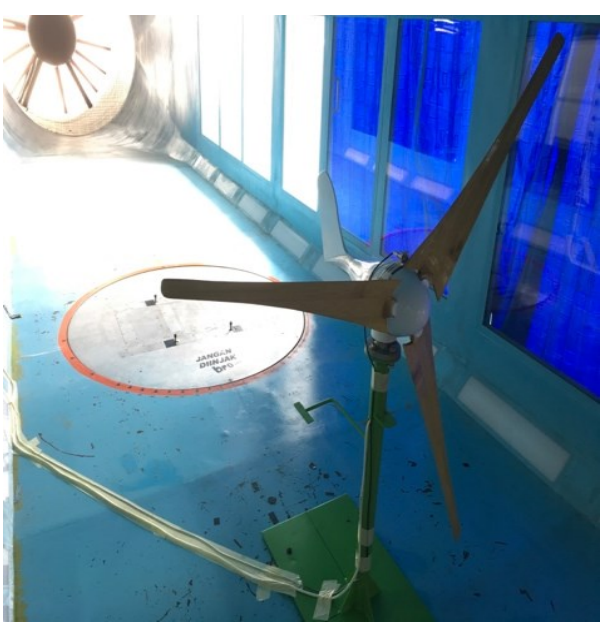

(b)

Fig. 1. (a) low-speed wind turbine using standard blade and (b) Low-speed wind turbine using LLBC Blade.

Measurement parameter of wind turbine performance comprises power and angular speed by varying wind speed in wind tunnel. Measurements are done in the LAPAN wind tunnel. The LAPAN wind tunnel is a wind tunnel open circuit with a test section width of $2325 \mathrm{~mm}$ and a height of $1743 \mathrm{~mm}$ and a total tunnel length of $11510 \mathrm{~mm}[6]$.

\section{Results and Discussion}

The results of measurement analyzed are the power generated on the electric circuit and the angular speed of the wind turbine. Figure 2 shows the graph of generated power as a function of wind speed. The electric power produced by LLBC-blade is lower than that produced by the standard blade (fiberglass) for all wind speed measurement. At wind speed of $8 \mathrm{~m} / \mathrm{s}$, we observed vibrations that reducing wind turbine performance. The vibration also occurs at the standard wind turbine when wind speed reaches $13 \mathrm{~m} / \mathrm{s}$. A possible cause of the great vibrations on the LLBC blade is mass distribution on the LLBC blade because the blade is made by handmade. Another thing to note is starting wind speed. The starting wind speed of standard blade is $4.7 \mathrm{~m} / \mathrm{s}$ and LLBC blade is $5.6 \mathrm{~m} / \mathrm{s}$. The difference in generated power between standard and LLBC blade is 20 watt when wind speed is $7.5 \mathrm{~m} / \mathrm{s}$.

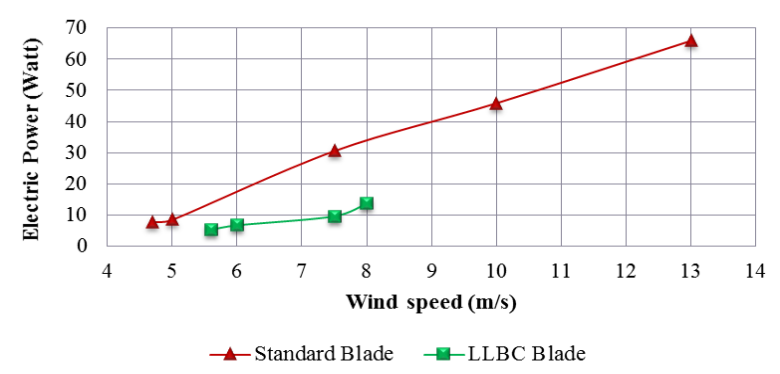

Fig. 2. Generated electrical power as a function of wind speed.
Figure 3 provides the graph of generated angular speed as a function of wind speed. The angular speed indicates the ability of the blade to capture kinetic energy of the wind to convert to electrical energy in a generator. In line with power generated, the angular speed generated by the LLBC blade is lower than that of the standard blade. This result indicates the need to optimize the geometry of the blade for improving performance.

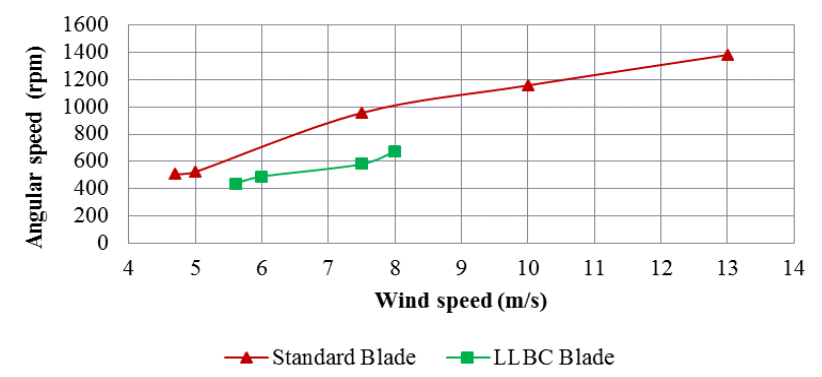

Fig. 3. Generated angular speed as a function of wind speed.

\section{Conclusion}

We have successfully produced LLBC-blade (made of gombong bamboo and AW106) for low speed wind turbine. The LLBC material has average tensile strength of 284.4 MPa. Based on wind tunnel experiment, the LLBC-blade generated electrical power of 13.8 watt at wind speed of $8 \mathrm{~m} / \mathrm{s}$ which is lower than generated by standard blade (fiberglass). Operating at wind speeds greater than $8 \mathrm{~m} / \mathrm{s}$ caused vibrations that reducing the performance. Based on this issue, further research is needed in terms of blade stability when rotating with the balancing process. In addition, it needs a redesign process on the airfoil and blade profiles. The process is expected to reduce the vibrations that occur and ultimately increase the performances of wind turbine. 
The authors would like to thank to Ministry of Research and Technology and Higher Education (MoRTHE) for financial support through research grant of Produk Terapan year 2017 and 2018.

\section{References}

1. Perusahaan Listrik Negara. Rencana Usaha Penyediaan Tenaga Listrik (RUPTL) PT. PLN (Persero) 2015 - 2024. (Jakarta: PLN. 2015)

2. El-Wakil, M.M., Power Plant Technology. Mc Graw-Hill. (1988)

3. International Electrotechnical Commissions (IEC) Standard 61400.

4. William D C and David G. R. Materials Science and Engineering: An Introduction $-9^{\text {th }}$ ed (Canada:Wiley and Sons). (2014)

5. Setiawan A., Al Gifari, M.M., Putra, R.H. Tensile strength improvement of LLBC based material for low speed wind turbine rotor blade by varying composite matrix. IOP Conf. Ser.: Mater. Sci. Eng. 288 012013. (2018)

6. Hartono, Firman, Ronald Bessie and Agus Ariwibowo. The Measurement of Turbulence and Flow Angularity in Lapan's Subsonic Wind Tunnel (Jurnal Teknologi Dirgantara Vol.14). pp 147-158. (2015) 